\title{
ANALYSIS OF ISLAMIC CONSUMPTION ETHICS CRITICAL TOWARD CAUSES OF CORONA VIRUS IN WUHAN, CHINA
}

\author{
Ahmad Maulidizen \\ STIMIK ESQ Business School, Jakarta Selatan, Indonesia \\ ahmad.maulidizen@esqbs.ac.id
}

Diterima 13-07-2020 | Direview 02-10-2020 | Diterbitkan 02-12-2020

\begin{abstract}
:
The last few days, the world was shocked by the appearance of a corona virus outbreak that attacked the plains of China. According to CNN Indonesia February 2020 there were 42,500 people reported to be infected with the corona virus worldwide, 947 people died from the virus that triggered this respiratory disorder and 25,000 were treated. This virus is known to originate from Hubei Province, precisely the city of Wuban. Therefore, there is an assumption that links the phenomenon of the emergence of the corona virus with the habits of the Wuban community that likes to consume wild animals, such as bats. So the purpose of writing this article is to find out how to analyze the ethical consumption of Islam and scholars about eating bats. This research is library research with a descriptive approach, namely by describing and critically analyzing the causes of the corona virus according to Islamic consumption ethics and the scholars. Data collection methods use documentation, various articles and books. Then analyzed using content analysis, critical analysis and data analysis methods deductively, inductively and comparatively. The results of this research are there are five ethics of Islamic consumption, namely monotheism, balance, responsibility, free will and the probibition of being royal (isräf) and must consume halala animals and provide benefits not bring danger to buman life. The scholars disagree in determining the law of consumption of bats, Shäfit and Hambali declare haräm, Mälikì declared makrūh and not until haräm, but not something that can be consumed, while Hanafi disagreed, there are those who declare halàl and some who argue not halall.
\end{abstract}

Keywords: Islamic Consumption Ethics; Corona Virus; Wuban China

\begin{abstract}
Abstrak:
Beberapa hari terakhir, dunia dikejutkan oleh kemunculan wabah virus korona yang menyerang dataran Cina. Menurut CNN Indonesia Februari 2020 ada 42.500 orang dilaporkan terinfeksi dengan virus korona di seluruh dunia, 947 orang meninggal karena virus yang memicu gangguan pernapasan ini dan 25.000 dirawat. Virus ini diketahui berasal dari Provinsi Hubei, tepatnya kota Wuhan. Karena itu, ada asumsi yang mengaitkan fenomena munculnya virus korona dengan kebiasaan masyarakat Wuhan yang gemar mengonsumsi hewan liar, seperti kelelawar. Jadi tujuan penulisan artikel ini adalah untuk mengetahui bagaimana menganalisis
\end{abstract}




\begin{abstract}
konsumsi etis Islam dan cendekiawan tentang makan kelelawar. Penelitian ini adalah penelitian kepustakaan dengan pendekatan deskriptif, yaitu dengan mendeskripsikan dan menganalisis secara kritis penyebab virus korona menurut etika konsumsi Islam dan para ulama. Metode pengumpulan data menggunakan dokumentasi, berbagai artikel dan buku. Kemudian dianalisis menggunakan analisis isi, analisis kritis dan metode analisis data secara deduktif, induktif, dan komparatif. Hasil dari penelitian ini adalah terdapat lima etika konsumsi Islam, yaitu taubid, keseimbangan, tanggung jawab, kehendak bebas, dan larangan bersikap loyal atau berlebihlebihan (isräf) dan harus mengkonsumsi hewan haläl dan memberikan manfaat tidak membawa bahaya bagi kehidupan manusia. Para ulama tidak setuju dalam menentukan hukum konsumsi kelelawar, Shāfi'ì dan Hambalī menyatakan harām, Mālikī menyatakan makrūh dan tidak sampai ḥarām, tetapi bukan sesuatu yang dapat dikonsumsi, sementara Hanafì tidak setuju, ada yang menyatakan haläl dan beberapa yang berdebat bukan halāl.
\end{abstract}

Kata Kunci : Etika Konsumsi Islam; Virus Corona; Wuhan China

\title{
Introduction
}

The research team from the Bogor Institute of Agriculture and the Research Center for Zoonosis Control at the University of Hokkaido in Japan found a type of virus in fruit bats that live in Indonesia. Coronavirus, bufavirus, polyomavirus, alphaherpesvirus, paramyxovirus, and gammaherpesvirus are said to potentially cause zoonoses and diseases transmitted from animals to humans.

According to Prof Agus, the six viruses in fruit bats all have the potential to cause zoonoses. It's just, it does not yet know the form of the disease when it infects humans. The research team found these viruses in bat samples taken from Bukittinggi in West Sumatera, Bogor and Panjalu in West Java, Gorontalo in Gorontalo Province, Manado in North Sulawesi, and Soppeng in South Sulawesi. The team conducted the research in 2010 to 2015 and published the results of research in 2012 to 2018

Based on the spread of two viruses found in fruit bats, the Nipah virus in Malaysia in 1998 and the Hendra virus in Australia in 1994, the research team wanted to find out whether the fruit bats in Indonesia, which were between the two countries, had the same virus. . In spreading nipah virus, from the bat the virus moves to the pig. Pigs exposed to the virus are not sick, but can transmit the virus to humans. The pattern of the spread of Hendra virus in Australia is almost the same pattern. From the bat the virus moves to the horse, which then transmits the virus to humans. Nipah virus and Hendra virus are 
transmitted from animal to animal then from animal to human. Agus explained that the viruses in fruit bats did not affect fruit bats because they have a unique immune system

The last few days, the world was shocked by the appearance of a corona virus outbreak that attacked the plains of China. According to Indonesian CNN 42,500 people were reported infected with the corona virus worldwide, 947 people died from the virus that triggered this respiratory disorder and 25,000 were treated. This virus is known to originate from Hubei Province, precisely the city of Wuhan. Therefore, there is an assumption that links the phenomenon of the emergence of the corona virus with the habits of the Wuhan community that likes to consume wild animals, such as bats. Then, what is the view of the scholars regarding the law of eating bats, including bat soup? The scholars differed in that regard? So the purpose of writing this article is to analyze the causes of the corona virus according to the ethical consumption of Islam and the scholars.

\section{Method}

This research is a library research with a descriptive approach, namely by describing and critically analyzing the causes of corona virus according to the ethical consumption of Islam and the scholars. Data collection methods use documentation, various articles and books. Then analyzed using content analysis and critical thinking, namely by analyzing the literature data that is descriptive. Data analysis methods are deductive, inductive and comparative.

\section{Discussion}

\section{General Description of Corona Virus}

Corona virus ${ }^{1}$ is virus which can cause on birds and mammals (including humans). ${ }^{2}$ This virion structure consists of membran, lipid bilayer (envelope), glikoprotein that resembles a nail (spike), genom RNA is positive, and nucleocapsid proteins. ${ }^{3}$ Coronavirus glycoprotein can bind to surface

\footnotetext{
${ }^{1}$ Glosarium Pusat Bahasa Departemen Pendidikan Nasional Republik Indonesia, "Entri lema koronavirus," 2020, https://101kfe.id/gejala-virus-corona-dan-cara-pencegahannya/. ${ }^{2}$ Wolfgang B. Fischer, Viral Membrane Proteins: Structure, Function, and Drug Design (London: Springer, 2005).

${ }^{3}$ Aaron J. Shatkin, Advances in Virus Research, vol. 66 (London: Academic Press, 2006).
} 
glycoprotein sel host specifically to start infection. ${ }^{4}$ Corona viruses are classified into three main groups, groups 1 and 2 infect mammals ranging from bats to humans, while group 3 is only found in avian species (birds). ${ }^{5}$ This virus infection can cause symptoms of a variety of diseases, ranging from almost no symptoms to fatal and rapid symptoms. ${ }^{6}$ Corona virus infection can cause various diseases, such as bronchritis, encephalitis, gastroenteritis and hepatitis. ${ }^{7}$

The 2019-2020 corona virus outbreak, known as the coronna virus or the Wuhan Corona virus or Wuhan Pneumonia, broke out in mid-December 2019 in Wuhan City, China, from several people with pneumonia whose cause is unknown. Some of them have shanties in the Huanan Fish Market which also sell live animals. A number of researchers in China have isolated the new coronavirus coded 2019-nCoV. At least 70\% of the 2019-nCoV genome sequence is the same as SARS-CoV.

WHO warns that this outbreak has the potential to spread, especially in the midst of the peak flow of the Chinese New Year homecoming. Some have questioned whether the virus has been circulating longer than expected, whether Wuhan was really the origin of the outbreak or just the location of the first discovery thanks to ongoing surveillance and testing, and is it possible that Wuhan developed into a case of superspreader. On January 22, 2020, the World Health Organization (WHO) emergency committee discussed whether the outbreak was classified as a public health emergency that is troubling the world according to the International Health Regulations and decided to reject the classification on January 23.

Disease Due to Corona Virus Infection As previously explained, Corona virus attacks the respiratory system. The impact of this virus infection is mild to severe even to cause death in sufferers. The following are 3 (three) types of diseases caused by Corona virus infection for you to be aware of;

1. Middle East Respiratory Syndrome (MERS)

The first disease caused by Coronavirus infection is Middle east respiratory syndrome or abbreviated as MERS. The disease that first appeared in Saudi Arabia and a number of other Middle Eastern countries (that's why the disease was named MERS) in 2012, as reported by WebMD has caused 858

\footnotetext{
${ }^{4}$ Volker Thiel, Coronaviruses: Molecular and Cellular Biology (London: Caister Academic Press, 2007).

${ }^{5}$ Volker Thiel.

${ }^{6}$ Wolfgang B. Fischer, Viral Membrane Proteins: Structure, Function, and Drug Design.

${ }^{7}$ Wolfgang B. Fischer.
} 
people died. The MERS death toll includes those from other countries outside Saudi Arabia and beyond, including the United States.

2. Severe Acute Respiratory Syndrome (SARS)

Long before the MERS outbreak emerged, precisely in 2003, there were also other dangerous diseases caused by Coronavirus infections. Is SARS, or Severe Acute Respiratory Syndrome. Just like MERS, this disease has claimed many lives, 774 to be exact from various countries in Asia, North America, South America and Europe. The new SARS outbreak was declared to end in 2015, based on no case reports received

3. Wuhan Coronavirus

As the name implies, this Corona virus outbreak originated in Wuhan city in Hubei Province, China. The World Health Organization then named this virus the Coronavirus novel (2019-nCoV). 18 people have died as a result of Wuhan Coronavirus infection. The outbreak of the disease is expected to continue along with the findings of new cases that have even reached other countries. Nevertheless, quoting from Sky News, WHO itself has not yet given a global disease status (pandemic) to the outbreak

Corona virus can be transmitted from animals to humans and between humans themselves. Here are the most common ways of transmitting Coronavirus (1) Direct contact with sufferers, (2) Exposure to sufferers (kisses, coughing, sneezing) and (3) Touching contaminated objects (mattresses, pillows, bolsters, sofas, tables, etc.) Coronavirus can affect anyone, regardless of age or gender. However, there are a number of risk factors that make a person more susceptible to this virus, namely (1) elderly people, (2) children and (3) people with weakened immune systems.

Coronavirus infection is characterized by symptoms that initially look like common cold symptoms. Here are the symptoms of the Corona virus that you should be aware of (1) Fever, (2) Nasal congestion, (3) Cough and (4) Sore throat. The absence of differences in symptoms between Coronavirus infection and infection with the common cold virus (Rhinovirus) makes you should immediately consult a doctor if you experience these symptoms, especially if the symptoms have been going on for a long time and do not heal after being given drugs. general medicine

To determine whether your complaint is related to Coronavirus, a doctor needs to carry out a series of examination procedures, which include; (1) Anamnesis, is the stage in which the doctor will ask a number of questions to the patient regarding the perceived complaint, (2) Physical examination, is the 
stage in which the doctor will examine the physical condition of the patient if it can lead to an infection. At this stage, the patient is also examined for blood pressure, height and weight, and (3) Investigation is the next step to confirm the diagnosis. Common types of investigations are blood tests and biopsy of saliva.

Specifically for the 2019-nCoV virus infection, scientists have yet to find a vaccine that can fight the attack, given the relatively new outbreak. The only thing that can be done is to do medical treatment as early as possible before the condition gets worse. Therefore, it is important for you to immediately see a doctor if you feel you have symptoms of infection as mentioned above, especially if you have risk factors. Some ways to treat Wuhan Coronavirus infections are as follows: (1) Provision of special flu and fever medicines (aspirin, ibuprofen, acetaminophen, etc.), (2) Increase fluid intake into the body, and (3) Get plenty of rest.

To avoid a wider spread of the virus, the doctor may recommend that the patient be isolated in a special room during the treatment period. Coronavirus infections can be prevented by ways such as (1) Avoiding contact with people with infections, (2) Use nose and mouth masks when outdoors, (3) Wash your hands with soap and warm water regularly, (4) Limit contact between hands with eyes, nose and mouth, (5) Drink plenty of water, and (6) increase consumption of fruits, vegetables, and vitamin supplements to increase body immunity

\section{Theoretical Basis of Consumption}

\section{a. Definition of consumption}

In defining consumption there are differences among economists, but consumption is generally defined by the use of goods and services to meet human needs. In Islamic economics, consumption also has the same meaning, but has a difference in each that surrounds it. The fundamental difference with conventional economic consumption is the goal of achieving consumption itself, how to achieve it must meet the rules of sharia guidelines. Consumers or people who use goods or services to meet their needs are called consumers. Consumer behavior is the tendency of consumers to consume, to maximize satisfaction. In other words, consumer behavior is the behavior of consumers, where they can illustrate the search for buying, using, evaluating and improving their products and services. Consumer behavior learns how humans choose among the various choices they face by utilizing their resources 


\section{b. The Urgency and Consumption Purpose}

Consumption has enormous urgency in every economy, because there is no life for humans without consumption. Therefore, economic activity leads to the fulfillment of human consumption demands. Because, ignoring consumption means neglecting life and also ignoring man's enforcement of his duties in life. In the economic system, consumption plays an important role. Consumption will drive production, distribution and drive the economy. ${ }^{8}$

The main purpose of consumption of a Muslim is as a means of helping to worship. Actually consuming something with the intention to increase stamina in obedience to the devotion to God will make consumption worth worship and get reward. Because an activity will become worship if accompanied by the intention of self-approach (taqarrub) to God, such as: eating, sleeping and working, if it is intended to increase the potential in serving God. In Islamic economics, consumption is considered as a mandatory means that a Muslim cannot ignore in realizing God's intended purpose in the creation of mankind, namely to realize fully devotion only to Him. (al-Dzāriyāt : 56). ${ }^{9}$

Meanwhile, consumption in the conventional economic perspective is considered as the greatest goal in life and all forms of human activity in it, both economic activity and not. Based on this concept, it circulates in the economy of what is called the theory: "The consumer is king". Where this theory says that all consumer desires are the direction of all economic activities to meet their needs according to the level of relative desirability of these desires. Even the theory holds that human happiness is reflected in its ability to consume what it wants.

\section{The Orientation of Consumption Ethics in Conventional Economics and Islamic Economics ${ }^{10}$}

Customer satisfaction is influenced by previous expectations that consumers have thought about the level of quality. Consumers form beliefs about product performance based on previous experience with products or

\footnotetext{
${ }^{8}$ Muhammad Quraish Shihab, Wawasan Al-Quran (Bandung: Mizan Pustaka, n.d.).

${ }^{9}$ Abdul Aziz, Etika Bisnis Perspektif Islam Implementasi Etika Islam Untuk Dunia Usaha (Bandung: Alfabeta, 2013).

${ }^{10}$ Melis, "Prinsip Dan Batasan Konsumsi Islami," Journal Islamic Banking, 1, 1 (2015): $13-20$.
} 
communication about products that imply a certain level of quality. ${ }^{11}$ In conventional economics, consumers are assumed to have the goal to obtain (utility) in their consumption activities. Untility literally means usefulness, helpfulness, or advantage. In the context of economic utility is interpreted as the use of goods perceived by a consumer when consuming an item. This use can also be felt as a sense of "belped" from a difficulty because of consuming the item. Due to this feeling, utility is often interpreted as a sense of satisfaction or satisfaction felt by a consumer in consuming an item. So, satisfaction and utility are the effects caused by utilities. ${ }^{12}$

Consumer behavior in conventional (capitalist) economic theory, some basic principles in the analysis of consumer behavior are ${ }^{13}$ (a) Scarcity and limited income. Scarcity and limited income compel people to make choices, so that expenditure stays within a predetermined budget, (b) Consumers are able to compare costs with benefits. If two goods provide the same benefits, consumers will choose the smaller costs, if to obtain two types of goods required the same cost, then consumers will choose goods that provide greater benefits, (c) Not all consumers can estimate the benefits correctly. When buying goods, the benefits may not be in accordance with the price to be paid, (d) Every item can be substituted with other goods. Thus consumers can get satisfaction in various ways, (e) Consumers are subject to the law of reduced satisfaction (The Law of Diminishing Marginal Utility). The more quantities of goods consumed, the smaller the additional satisfaction produced. ${ }^{14}$

\section{Principles in the Ethics of Islamic Consumption}

According to Abdul Mannan, in conducting consumption there are five principles, namely; ${ }^{15}$

\section{a. The Principle of Justice}

This principle contains a dual meaning regarding seeking halal wealth and is not prohibited by law. That is, something consumed is

\footnotetext{
${ }^{11}$ Nor Marini Mohatar, “Ayamas Food Corporation Sdn,” Journal Social and Behavioural Sciences, 2014, 170.

${ }^{12}$ M. Arif Mufraini, Akuntansi Dan Manajemen Zakat Mengomunikasikan Kesadaran Dan Membangun Jaringan, 1 (Jakarta: Kencana Prenada Media Group, n.d.).

${ }^{13}$ Abdul Wahid, Ekonomi Islam: Analisis Mikro Dan Makro (Yogyakarta: Graha Ilmu, 2018).

${ }^{14}$ Annisa Masruri Zaimsyah and Sri Herianingrum, “Tinjauan Maqāṣid Sharī’ah Terhadap

Konsumsi," Ulumuna: Jurnal Studi Keislaman, 1, 5 (2019): 22-33.

${ }^{15}$ Ikhawan Aulia Fatahillah, "Implementasi Konsep Etika Dalam Konsumsi Perpsktif

Ekonomi Islam,” Jurnal Hukum Islam, 1, XIII (2013): 154-69.
} 
obtained lawfully and is not contrary to law. Consuming cannot cause wrongdoing, be in the corridor of religious rules or laws, and uphold propriety or goodness. Islam has various provisions regarding economic objects which may be consumed and those which may not be consumed. "O people, eat halal well from what is on earth" (al-Baqarah $2: 169)$. Justice in question is consuming something that is halal (not haram) and good (does not harm the body). Allowance is given for people who are forced to, and for people who one day do not have food to eat. He may eat only prohibited foods that are considered necessary for his needs at that time

\section{b. Cleanliness Principle ${ }^{16}$}

Clean in the strict sense is free from dirt or disease that can damage the physical and mental human, for example: food must be good and suitable to eat, not dirty or disgusting so that it damages the taste. While in the broadest sense is free from everything that is blessed by God. Of course the object consumed has benefits not waste or even damage.

\section{c. The Principle of Simplicity}

Excessive attitude (isräf) is very hated by God and is the base of various damage on earth. This exaggerated attitude implies that it exceeds natural needs and tends to discourage passions or is otherwise too stingy so that it tortures oneself. Islam requires a quantity and quality of consumption that is reasonable for human needs so as to create efficient and effective consumption patterns individually and socially.

\section{d. The Principle of Generosity}

Allah generously provided food and drink for humans (al-Maidah: 96). Then the nature of human consumption must also be based on generosity. That is, if there are still many people who lack food and drink then we should set aside the food that is available to us, then we give it to those who really need it. By obeying the teachings of Islam there is no danger or sin when consuming halal economic items provided by Allah because of His mercy. During this consumption is an effort to meet the needs that bring benefits to life and the role of humans to increase devotion to Allah, God has given His grace to humans. ${ }^{17}$

\section{e. The Principle of Morality}

\footnotetext{
16 et.al Muhammad Deni Purba, "Prinsip Konsumsi 4K + 1M Dalam Perspektif Islam," Asy-Syar'iyyah: Jurnal Ilmu Syriah Dan Perbankan Islam, 1, 4 (2019): 23-45.

${ }^{17}$ Lukman Fauroni, "Tafsir Ayat-Ayat Tentang Konsumsi (Aplikasi Tafsir Ekonomi alQuran)," Jurnal Millah, 1, VII (2008): 123-44.
} 
In the end the consumption of a Muslim as a whole must be framed by the morality contained in Islam so that it does not merely fulfill all needs. God provides food and drink for the survival of humanity in order to improve moral and spiritual values. A Muslim is taught to say the name of Allah before eating and express his gratitude after eating. The principle of morality implies that the behavior of consumers must submit to applicable Islamic norms. These five principles become a guideline for consumption activities that are in line with Islamic teachings. As according to Yūsuf Qarḍawī, the principles of consumption in the Islamic economy are: Stay away from the nature of misery and use of wealth in good, fight the excellence in consumption, and be modest in consumption. ${ }^{18}$

From some references that the authors collect, it can be concluded that the ethics of Islamic consumption as follows;

1) Taubid, ${ }^{19}$ in consuming, the nature of monotheism is the main basis for a Muslim to consume, in this case, a Muslim must really apply it. A Muslim believes that everything that exists is not created in vain, but everything that is created has a purpose. The purpose of being created by humans is to worship. Because all human activities in relation to nature and human resources are related to Allah, besides that, Allah created humans as well as khalifah on earth to protect the earth from damage. ${ }^{20}$

2) Balance. Islam forbids wasteful attitudes, miser and waste of wealth. This is the form of balance ordered in the Qur'an which reflects the attitude of justice in consumption. ${ }^{21}$

3) Responsible. The responsibility in consuming it is intended is the responsibility of humans as khalifah, this responsibility is related to human responsibility as khalifah towards managing natural resources in this world, also related to protecting the environment. Humans must be responsible for what they have done, so in consuming plastic products, a Muslim must be responsible for preserving the environment such as recycling the plastic

\footnotetext{
${ }^{18}$ Muhammad Nejatullah Siddiqi, Kegiatan Ekonomi Dalam Islam, 2nd ed. (Jakarta: Bumi Aksara, 1996).

${ }^{19}$ Bambang Hermanto, "Dasar Filosofis Pertumbuhan Ekonomi, Distribusi Dan Konsumsi

Dalam Ekonomi Islam,” Al-Fikra: Jurnal Keislaman, 2, 10 (2011): 333-59.

${ }^{20}$ Bambang Hermanto.

${ }^{21}$ Rozalinda, Ekonomi Islam: Teori Dan Aplikasinya Pada Aktivitas Ekonomi (Jakarta: Rajawali Pres, 2015).
} 
products.

4) Free Will. Freedom means free to do the will of man, but this freedom is not merely free to do as people want, but will by following the Islamic rules. Consuming freely by not creating kumdhoratan in the environment and other people.

5) the prohibition of being Royal and futile. ${ }^{22}$ Islam forbids humans to behave royal (Israf) and in vain, so Islam forbids luxurious lifestyles that can damage individuals and society because of preoccupying humans with lust, melinda from things that are noble and noble character. Rule Considering Consumption Priority, i.e., where consumers must pay attention to the order of interests that must be prioritized in order to avoid kemudharatan, namely: (1) Primary, namely basic consumption that must be met so that humans can live and uphold the benefit of themselves, the world and their religion and their closest people, namely the basic livelihoods for humans that can realize the five objectives of the Shari'a (namely maintaining soul, reason, religion, descent and honor). Without the primary needs of human life will not take place. These needs include the need for food, drink, shelter, health, security, knowledge and marriage, (2) Secondary, namely consumption to increase / improve a better quality of life, namely human needs to facilitate life, in order to avoid difficulties. These needs do not need to be fulfilled before primary needs are met, and (3) Tertiary, that is, needs that can create goodness and prosperity in human life. Meeting these needs depends on how the primary and secondary needs are met.

\section{The Concept of Mașlahah in Islamic Consumption Behavior ${ }^{23}$}

In Islam's view satisfaction is based on a concept called maslahah. AlShatibi uses the term maslahah, the meaning of which is broader than just utility or satisfaction in conventional economic terminology. According to al-Shātịīi, maslahah is the nature or ability of goods and services that support the basic elements and objectives of human life on this earth. There are five basic elements according to him, namely: life or soul (al-nafs), property or property (al-mäl), belief (al-din), intellectual (al-'aql), and family or descendants (al-nasl). ${ }^{24}$

\footnotetext{
${ }^{22}$ Imahda Khoiri Furqon, “Teori Konsumsi Dalam Islam,” Jurnal Hukum Dan Ekonomi Syariah, 1, 6 (n.d.): 1-18.

${ }^{23}$ Nasrun Haroen, Usul Fiqh (Jakarta: Logos Wacana Ilmu, 2013).

${ }^{24}$ Asyraf Wajdi Dusuki, "Maqāṣid Sharī’ah, Mașlaḥah, and Corporate Social Responsibility," The American Journal of Islamic Social Sciences, 2017.
} 
All goods and services that support the achievement and maintenance of the five elements mentioned above to each individual, that is what is called maslahah. Economic activities including production, consumption and exchange relating to the maslahah must be carried out as a religious duty or worship. The goal is not only satisfaction in the world but also prosperity in the afterlife. All these activities, which have problems for humanity, are called 'needs'. And all these needs must be met. Meeting the needs and not fulfilling the satisfaction / desire is the goal of Islamic economic activities, and the effort to achieve that goal is one of the obligations in religion. ${ }^{25}$

As for the characteristics of maslahah as follows: (1) Mașlahah is subjective in the sense that each individual becomes the judge of each in determining whether an action is a maslahah or not for himself. However, different from the concept of utility, the criteria for maslahah have been determined by sharia and are binding for all individuals, (2) Mașlahah individually will be consistent with the mas lahah of many people. This concept is very different from the Pareto Optimum concept, which is the optimal state in which a person cannot increase his level of satisfaction or well-being without causing a decrease in the satisfaction or welfare of others, and (3) The concept of maslahah underlies all economic activity in society, be it production, consumption, and in exchange and distribution

Based on the five elements above, maslahah can be divided into two types: first, the issue of the elements concerning the life of the world and the hereafter, and second: the problem for the elements concerning only the afterlife. Thus an Islamic individual will have two types of choices (1) What portion of his income will be allocated to the first type of maslahah and how much to the second type of maslahah, and (2) How to choose within the first type of maslahah: what portion of his income will be allocated to meet the needs of world life (in order to achieve satisfaction in the afterlife) and how many parts for the needs of the afterlife.

At a certain level of income, Islamic consumers, because they have allocations for matters relating to the afterlife, will consume less goods than non-Muslims. The thing that limits it is the concept of the above problem. Not all goods or services that provide satisfaction / utility contain maslahah in them, so not all goods or services can and are fit for consumption by Muslims.

\footnotetext{
${ }^{25}$ Abdullah, "Risk Management via Takaful from a Perspective of Maqasid of Shariah," Journal of Social and Behavioral Sciences, 2002.
} 
In comparing the concept of satisfaction with the fulfillment of needs (which is contained in the maslahah), we need to compare the levels of the objectives of maquașid shariah namely; (1) Darüriyyah: The goal of Daruriyyah is a goal that must exist and is fundamental for the creation of prosperity in the world and the hereafter, which includes the maintenance of five basic elements of life namely soul, belief or religion, intellect, descent and family and property. If the purpose of daruriyyah is ignored, then there will be no peace, what arises is damage (facade) in the world and real loss in the afterlife.

(2) Häjiyyah: Shari'ah aims to facilitate life and eliminate narrowness. Islamic law in this category is not intended to preserve the five main points but rather to eliminate narrowness and be careful of the five main points, and (3) Tahsiniyyab: sharia requires a beautiful and comfortable life in it. There are several provisions in sharia that are intended to achieve better utilization, beauty and simplification of darüriyyah and hajizyah. For example he was allowed to wear comfortable and beautiful clothes. ${ }^{26}$

\section{Critical analysis of consumption of bats and other fanged animals according to Sharīah}

\section{a. The Definition of Haläl and Harām}

Hal is anything that is allowed by God to be eaten and contains benefits for our body. While Haram is anything that is not allowed by God to be eaten and does not contain benefits but harms. Therefore the Prophet Muhammad once said "Any meat that grows from something unclean then hell is more appropriate for him". The origin of all food is permissible and lawful until there is an argument that states its prohibition. Allah says: "He is Allah, Who made everything on earth for you". (al-Baqārah: 29) This verse shows that everything (including food) on earth is a blessing from God, so this shows that the original law is lawful and permissible, because God does not give pleasure except lawful and good.

\section{b. Halāl animals for consumption}

The general proposition referred to here is the basis taken from the Qur'an and Hadith which shows the helall of animals in general. Included in the types of halal animals based on common propositions are (1) Land animals. such as: goats, sheep, cattle, buffaloes and camels (al-Maidah: 1), (2) Sea animals (water), all animals that live in water in the form of fish or

\footnotetext{
${ }^{26}$ Ikhawan Aulia Fatahillah, "Implementasi Konsep Etika Dalam Konsumsi Perpsktif Ekonomi Islam,.”
} 
other, except those that resemble unclean animals such as dogs sea, according to Islamic law the law is halal eaten (al-Maidah: 96).

Whereas haläl animals based on special arguments are types of haläl animals which are directly referred to through certain propositions are (a) Horses, are animals that are halal eaten because it is specifically stated in the following hadiths "In the time of the Prophet we had slaughtered horses and we ate them" (HR Bukhārī and Muslim), (b) Wild Donkeys, Donkeys that are wild, including haläl animals are eaten because they are specifically stated in the following hadith: Wild Donkeys, Wild donkeys, including wild animals are eaten because they are specifically stated in the Prophet's hadith the following: "About the story of wild donkeys, the Prophet ate some of the donkey's meat". (HR Bukhārī and Muslim)

(c) Chicken, including haläl animals are eaten because it is specifically stated in the following hadith of the Prophet: "I have seen the Prophet eat cbicken meat" (HR Bukhārī and Tirmizī), (d) Grasshopper, is an animal that is haläl eaten because specifically stated in the following hadith: "We fought with Prophet seven times a war, we ate grasshoppers" (HR. Bukhārī and Muslim), and (e) Rabbits. Narrated from Anas bin Malik he said: "When we walked through the area of al-Zahran we were suddenly shocked by a rabbit and then we chased bim so tired. He said again: I have pursued him so that he can catch him. I also brought it to Abu Talhah then he slanghtered it. He sent his legs and thighs to the Messenger of Allah and then I brought them to Rasulullah s.a.w and His Majesty received them" (HR Bukhārī and Muslim).

\section{c. Unlawful animals for consumption}

Muslims can know about the haram of an animal through three things, namely: General theorem, namely: the argument that only mentions the nature of animals, so it is haram consumed by Muslims. There are three types of animals that are unclean based on general proposition because it has a nature that is feared to be very easy to switch on humans. The three types of animal characteristics are (1) Having a wild and fanged nature, such as: tiger, leopard, dog, bear. The Prophet said: "Any wild animal that is fanged, forbidden to eat" (HR Muslim and Turmuzi).

(2) Every animal with sharp hooves, such as: eagles, eagles, parrots, and owls. The Prophet said "The Messenger of Allah has forbidden (eaten) every bird with sharp hooves" (HR.Muslim), and (3) Every animal that eats poop, such as: flies, the Prophet said: "From Ibn Umar said," The Prophet Mubammad forbade eating animals are (dung-eating animals) and drink their milk." 
(HR. Arba'ah except Nasā'̂̀). Also included in this category of animals are animals that are dirty and generally disgusting, such as: mites, fleas, cockroaches, and the like. "And it is permissible for them all that is good and forbidden for them all that is bad (bad)" (al-A'raf: 157).

Unlawful animals through Husus theorem that is, the proposition that directly mentions the prohibition of certain types of animals. There are seven types of animals that are forbidden to be eaten by Muslims because each is called by an argument that forbids it. The seven types of animals are (1) Pork (al Maidah: 3), (2) Khimar or tame donkey. "The Prophet has forbidden to eat benign khimar meat and permitted horse meat" (HR Bukhārī and Muslim), (3) It is forbidden to kill him, such as: suradi birds, frogs, ants, and hud-huds. "The Messenger of Allah has forbidden to kill suradi birds, frogs, ants, and budhud birds" (HR. Ahmad), (4) Frogs, "Indeed, a physician asked the Prophet about frogs for medicinal purposes, the Prophet forbade killing him" (HR. An-Nasai ).

\section{d. The impact of consumption of halal and harām animals for consumption such as bats}

If the haläl animals provide many benefits for humans, of course, unclean animals will provide harm to humans. Prohibited animals are animals that have bad traits, such as dirty, disgusting, cruel, living in two realms (land and water), and so forth. If we consume food that comes from animals that have bad traits it is feared we will also have the same traits as these animals. As for some harmful animals that are forbidden if consumed (1) Causing the outbreak of disease, (2) Influencing mental and human behavior, (3) Encouraging acts that are forbidden by God, (4) Sinning and getting punished from hell, and (5) Causing deeds of worship and prayer rejected by God.

Animals have quite a number of functions and benefits for humans, such as for riding (transportation), helping to carry human burdens, for plowing the fields, and their meat can be eaten. This haläl animal helps humans to make ends meet in terms of food. From this animal flesh, humans get enough protein and nutrients that are needed by our body to strengthen stamina. By consuming halal animals, there is a balance of protein in our body between vegetable protein (derived from plants) and animal protein (derived from animals).

The animals we slaughter and eat will never hold grudges in the afterlife, because these animals have no reason and will not be revived in 
the afterlife like humans. These animals would rather be able to die quickly by being slaughtered and then eaten, rather than die in vain and suffer from old age or prolonged illness. As for some of the benefits of halal animals, namely (1) Nourish the body and avoid disease, (2) Soothe the soul so that his life is not agitated, (3) Encourage someone to be a clean servant, (4) Encourage a person to always be grateful for favors God, (5) Add special devotion to worship, and (6) Save yourself from sin from the torments of hellfire

\section{e. The Consumption of Bats According to Scholars}

Jumhur Ulama include Shāfi'î, Hanbalī, and some Hanafī scholars assert that bats are haram. Ibn Abidin said: "According to our mazhab, it is permissible to eat swallows and owls, it is permissible to eat shurads and bud-buds. Meanwbile, the law of eating bats is debated". ${ }^{27}$ Ibn 'Ābidīn also stated," And bats are strictly forbidden". Rāfi'ī said: "And sometimes there are differences of opinion regarding the bat law". ${ }^{28}$ The same thing was revealed in another Shāfi'i book, Hasyiyata Qalyubi wa Umairah as follows: "And said al-khutaf for the type of bat animal, namely al-wathwhat, which is also haram". ${ }^{29}$

As for Hanbali's opinion about bats conveyed by Ibn Qudāmah, "And it is forbidden to eat al-khutaf, al-khussyaf, and al-khuffash, that is bats. These animals are forbidden because of disgusting". ${ }^{30}$ Secondly, Maliki states, "bats are unlawfully eaten". Al-Shawi said: "Including food that is eaten is al-watwat, by giving baha fathah to the letter wawn, which is bat" "31 Third, some other Hanafí scholars claim that bats may be eaten. Ibn 'Ābidin: "According to our school, it is permissible to eat swallows and owls, it is permissible to eat shurads and hud-buds. Meanwhile, the law of eating bats is debated (some forbidding, and some allow)". ${ }^{32}$

Thus it can be concluded that the scholars disagree about the law of eating bats, including bat soup. The majority of scholars include Shāfi'̄',

\footnotetext{
${ }^{27}$ Ibn 'Ābidin, Muḥammad 'Alā al-Dīn Afnadī, Radd Al-Mukhtār 'ala al-Durr al-Mukhtār (Beirut: Dār al-Ma’rifah, 2011).

${ }^{28}$ Al-Nawawī, Abū Zakariyyā Muḥȳ̄ al-Dīn bin Sharaf, Majmū’ Sharh al-Muhadhdhdab (Beirut: Dār al-Fikr, n.d.).

${ }^{29}$ Ibn 'Ābidin, Muḥammad 'Alā al-Dīn Afnadī, Hạsyiyah Ibn 'Ābidīn (Beirut: Dār alMa'rifah, 1966).

${ }^{30}$ Ibn Qudāmah, 'Abd Allāh Ibn Aḥmad al-Maqdisī, Al-Mughn̄̄ Wa al-Sarḥ al-Kabīr (Beirut: Dār al-Kutub al-'Arabi, 1972).

${ }^{31}$ Al-Șāwī, Aḥmad bin Muḥammad, Hāsyiyah Al-Ṣāwī 'Alā al-Syarh al-Ṣaghīr (Beirut: Dār al-Ma'rifah, n.d.).

${ }^{32} \mathrm{Ibn}$ 'Ābidin, Muḥammad 'Alā al-Dīn Afnadī, Hāsyiyah Ibn 'Ābidīn.
} 
Hanbalī, and some Hanafî scholars forbid it. Mālikī scholars punished makrūh. While some other Hanafi scholars allow it. Of the three opinions, it seems that opinion that forbids bat is a strong opinion, because bats are animals that are unnaturally eaten and are considered disgusting.

In addition, bats are animals that are forbidden to be killed, so it is also forbidden to eat, because it is impossible to eat bats without killing them. 'Abd Allah Ibn 'Amr narrated a hadith: "Do not kill you frogs. Surely the chirp is prayer beads. And you do not kill bats. Because, when Baitul Maqdis was burned, the bats prayed to Allab' 'O our Lord, I speak to the sea so that I can kill the bats. drown them". (HR. Baihaqi). However, if an emergency forces a person to eat bats, such as to treat an illness, it is permissible to eat them according to the Shāfi'î, as long as there is no other medicine that can replace them. That is because the benefit of being healthy and safe takes precedence over the benefit of staying away from unclean things.

\section{Simpulan}

Based on the description above it can be seen that the ethics of Islamic consumption are monotheism, balance, responsibility, free will and the prohibition of being royal or wasteful. Consumers must also prioritize the sequence of interests that must be prioritized to avoid hazards such as primary, secondary and tertiary needs. Islam encourages humans to consume halal animals because it will bring benefits rather than harm. While the scholars disagree in determining the law of consumption of bats, Shafi'i and Hambali declare haram, Maliki declared makrub and not until haram, but not something that can be consumed, while Hanafi disagreed, there are those who declare halal and some who argue not halal.

\section{Daftar Pustaka}

Aaron J. Shatkin. Advances in Virus Research. Vol. 66. London: Academic Press, 2006.

Abdul Aziz. Etika Bisnis Perspektif Islam Implementasi Etika Islam Untuk Dunia Usaha. Bandung: Alfabeta, 2013.

Abdul Wahid. Ekonomi Islam: Analisis Mikro Dan Makro. Yogyakarta: Graha Ilmu, 2018.

Abdullah. "Risk Management via Takaful from a Perspective of Maqasid of Shariah." Journal of Social and Behavioral Sciences, 2002. 
Al-Nawawī, Abū Zakariyyā Muḥȳì al-Dīn bin Sharaf. Majmū' Sharh alMuhadhdhdab. Beirut: Dār al-Fikr, n.d.

Al-Ṣāwī, Aḥmad bin Muḥammad. Hāsyizah Al-Sạañ 'Alā al-Syarh al-Ṣaghìr. Beirut: Dār al-Ma'rifah, n.d.

Annisa Masruri Zaimsyah and Sri Herianingrum. "Tinjauan Maqāṣid Sharīah Terhadap Konsumsi." Ulumuna: Jurnal Studi Keislaman, 1, 5 (2019): 2233.

Asyraf Wajdi Dusuki. "Maqāṣid Sharî̀ah, Maṣlaḥah, and Corporate Social Responsibility." The American Journal of Islamic Social Sciences, 2017.

Bambang Hermanto. "Dasar Filosofis Pertumbuhan Ekonomi, Distribusi Dan Konsumsi Dalam Ekonomi Islam." Al-Fikra: Jurnal Keislaman, 2, 10 (2011): 333-59.

Glosarium Pusat Bahasa Departemen Pendidikan Nasional Republik Indonesia. "Entri lema koronavirus," 2020. https://101kfe.id/gejalavirus-corona-dan-cara-pencegahannya/.

Ibn 'Ābidin, Muḥammad 'Alā al-Dīn Afnadī. Hāsyiyah Ibn 'Ābidīn. Beirut: Dār al-Ma'rifah, 1966.

—. Radd Al-Mukhtär 'ala al-Durr al-Mukhtär. Beirut: Dār al-Ma'rifah, 2011. Ibn Qudāmah, 'Abd Allāh Ibn Aḥmad al-Maqdisī. Al-Mughnī Wa al-Sarh alKabìr. Beirut: Dār al-Kutub al-'Arabi, 1972.

Ikhawan Aulia Fatahillah. "Implementasi Konsep Etika Dalam Konsumsi Perpsktif Ekonomi Islam,." Jurnal Hukum Islam, 1, XIII (2013): 154-69. Imahda Khoiri Furqon. "Teori Konsumsi Dalam Islam." Jurnal Hukum Dan Ekonomi Syariah, 1, 6 (n.d.): 1-18.

Lukman Fauroni. "Tafsir Ayat-Ayat Tentang Konsumsi (Aplikasi Tafsir Ekonomi al-Quran)." Jurnal Millah, 1, VII (2008): 123-44.

M. Arif Mufraini. Akuntansi Dan Manajemen Zakat Mengomunikasikan Kesadaran Dan Membangun Jaringan. 1. Jakarta: Kencana Prenada Media Group, n.d.

Melis. "Prinsip Dan Batasan Konsumsi Islami." Journal Islamic Banking, 1, 1 (2015): 13-20.

Muhammad Deni Purba, et.al. "Prinsip Konsumsi 4K + 1M Dalam Perspektif Islam.” Asy-Syar'iyyah: Jurnal Ilmu Syriah Dan Perbankan Islam, 1, 4 (2019): 23-45.

Muhammad Nejatullah Siddiqi. Kegiatan Ekonomi Dalam Islam. 2nd ed. Jakarta: Bumi Aksara, 1996.

Muhammad Quraish Shihab. Wawasan Al-Quran. Bandung: Mizan Pustaka, n.d. 
Nasrun Haroen. Usul Figh. Jakarta: Logos Wacana Ilmu, 2013.

Nor Marini Mohatar. "Ayamas Food Corporation Sdn." Journal Social and Behavioural Sciences, 2014, 170.

Rozalinda. Ekonomi Islam: Teori Dan Aplikasinya Pada Aktivitas Ekonomi. Jakarta: Rajawali Pres, 2015.

Volker Thiel. Coronaviruses: Molecular and Cellular Biology. London: Caister Academic Press, 2007.

Wolfgang B. Fischer. Viral Membrane Proteins: Structure, Function, and Drug Design. London: Springer, 2005. 